\title{
Claude Marcel (1793-1876): A Neglected Applied Linguist?
}

\author{
RICHARD SMITH \\ University of Warwick, UK
}

This article contributes to the as yet underexplored field of applied linguistic historiography by surveying the life and achievements of Claude Marcel (1793-1876), author of a two-volume study of language education published in London in 1853 under the title Language as a Means of Mental Culture and International Communication. The question of whether Marcel was an applied linguist 'avant la lettre' is addressed, as are possible reasons for the contemporary and subsequent neglect of his work. It is suggested that the identification of precursors depends on one's view of the nature of applied linguistics, and that there are alternatives to a linguistics-focused conception. Indeed, a consideration of Marcel's writings - and the contemporary and subsequent neglect of them - highlights the way language teaching theory has tended, for the last 120 years or more, to be dominated by linguistic much more than educational considerations.

KEYWORDS applied linguistics (history of), language teaching (history of), French language

\section{Introduction}

Claude Marcel (I793-I876), who served in Cork as an official representative of the French government between I8I6 and $c$. I864, was additionally an innovative teacher of French and the author of a two-volume study of language education published in London in 1853 under the title Language as a Means of Mental Culture and International Communication; or, Manual of the Teacher and the Learner of Languages. For Howatt (1984/2004: 174), 'there is no single work in the history of language teaching to compare with it for $[\ldots]$ strength of intellect $[\ldots]$ breadth of scholarship

This article is based on a paper originally presented at the BAAL/IRAAL Annual Conference, 'From Applied Linguistics to Linguistics Applied: Issues, Practices, Trends', University College, Cork, Ireland, in September 2006. I wish to acknowledge the previous research by A. P. R. Howatt on which it builds and the helpful comments of two anonymous reviewers for this journal. The paper was originally prepared very much with the life and applied linguistic philosophy of Professor Christopher Brumfit (1940-2006) in mind, and I dedicate this article to his memory. 
[...] and [...] wealth of pedagogical detail', with the possible exception of Henry Sweet's (I899) The Practical Study of Languages. Should we not, then, consider Claude Marcel a major pioneer of applied linguistics, comparable in this respect with figures like Sweet (I845-I9I2) and Harold E. Palmer (I877-I949)? Although his work had little apparent influence on his contemporaries, Marcel's principled and systematic approach to the elaboration and selection of teaching methods seems at first sight to qualify him as an early applied linguist of some stature. In this article I present original findings relating to Marcel's overall career and writings as a basis for considering further the question of Marcel's status - or otherwise - as an applied linguist avant la lettre. In so doing, I hope to contribute a fresh perspective in the as yet underdeveloped area of applied linguistic historiography. Thus, while Linn (2008) - who also remarks on a relative dearth of research in this area - has recently made a convincing case for the 'birth of applied linguistics' in Anglo-Scandinavian work of the late nineteenth century, I shall suggest, taking Marcel's work as a case in point, both that the identification of precursors depends very much on one's view of the nature of applied linguistics and that alternatives to a linguistics-focused conception may deserve greater consideration. ${ }^{\mathrm{I}}$

\section{Marcel's career and writings}

Born and educated in Paris, Marcel served for a brief period in Napoleon's Imperial Guard but was invalided out with a shoulder injury received in Holland in January I $8 \mathrm{I} 4 .{ }^{2}$ In I8I6 he took up an honorary post as Chancellor in the French Consulate in Cork, which at that time had considerable direct trade links with France: thus the position was far from being a sinecure (Coleman, I909: I00). Marcel, according to one local historian, 'married a Cork lady and became a prominent and favourite figure in the Cork social life of his day' (ibid.). Indeed, he was to stay in Cork until at least the mid I86os. Early on, probably to help make ends meet, he began to engage in French language teaching, and the Southern Reporter of I9 October I8I9 carried an advertisement stating that he had 'opened a French Practical School' in South Mall in the city. Little more is known about his teaching or business activities at this time, except what can be inferred from his books, the first of which (Marcel, I820) was published in London in the year following the opening of his school.

In this 82-page essay, Marcel points out the defects of what he calls the 'Old Method' and suggests remedies, with a particular emphasis on the requirements of

\footnotetext{
I As Linn (2008: 348) recognizes, applied linguistics 'is a very broad church', and there are 'differing opinions today about what applied linguistics involves'. Contradictions are evident even in the definition offered by the Association Internationale de Linguistique Appliquée (AILA) which is cited by Linn (ibid.). This begins with the statement that 'Applied Linguistics is an interdisciplinary field of research' but, later in the very same sentence, seems to privilege the notion of 'applying [...] Linguistics'. In taking from this the idea that 'applied linguistics is about using insights from the academic discipline of linguistics to address [...] "real-world problems"', Linn (ibid.) seems careful not to ally himself with extreme forms of 'linguistics applied' (Widdowson, e.g. 2000); nevertheless, linguistics is privileged, and the insights into language-related real-world problems that can be gained from disciplines other than linguistics are, in this conception, to some extent at least, denied.

2 Biographical information relating to Claude Marcel is derived from Anon. (I982) except where stated otherwise.
} 
classroom teaching. He rails against contemporary modes of instruction (I820: I3), noting that, in proportion to the increase in numbers of pedagogical grammars on the market, 'masters have relaxed in their duty by referring their pupils, for information, to books frequently unintelligible and obscure, and most of which fall far short of their proposed object' (ibid.). Marcel himself sees a role for grammar instruction, but in a form better suited to the classroom. His suggested procedure is as follows:

The pupils sit facing a large blackboard, and the teacher explains a rule or two of the grammar each day, comparing the mother tongue and the foreign language, and illustrating the new rules with numerous written examples. (I820: 50-5I)

'Then', Marcel explains, 'the pupils should be successively called on to repair to the board, and explain to the other scholars, under the eye of the master, the rule already given by him' (I820: 5I). Students then write on slates the French sentences written on the board, a procedure which is said to maintain their attention, give them practice in writing French, and aid memorization (I820: 52). Between lessons, pupils prepare on slates or paper French sentences of their own which exemplify the rules last explained. The following lesson, pupils are called upon to explain the rules again and give their examples, and thus, Marcel claims, they are by degrees enabled to write without mental translation (I820: 52-53).

Marcel's emphasis on the importance of 'thinking in French' (г820: 60) contrasts with the reliance placed on translation by his better-known contemporaries James Hamilton (I769-I829) and Joseph Jacotot (I770-I840) (see Howatt and Smith, 2000). Indeed, his approach appears to prefigure later Direct Method teaching ideas: 'according as the words of any language are oftener read or heard, oftener spoken or written, without the assistance of translation, they become in the same proportion more familiar and natural' (Marcel, I820: 6I). Marcel emphasizes the development of separate language skills, adopting a point of view which is now familiar but which was unique at the time, that there are four objectives to attain (skills to develop) in mastering a foreign language: to speak, to understand what is spoken, to write, and to understand what is written (I820: 48-49).

The emphasis on the development of speaking and listening abilities in Marcel's I820 essay (to be mitigated somewhat in his later work by the priority placed there on reading) rests on an important and innovative distinction which he draws between the learning of the native tongue, a foreign living language, and a dead language, each requiring different means in their 'acquirement' (I820: I7-I8). This distinguishes him from his contemporary Jacotot (I824), who claimed that his system was equally applicable to literacy instruction in the mother tongue and in foreign languages and who placed no emphasis on the need to acquire speaking or listening proficiency. Indeed, Jacotot's examples are all taken from the learning of Latin, and he does not differentiate this from the learning of living languages. Another contemporary, James Hamilton, who began his career as a teacher of French, issued textbooks also for a number of other languages including Latin and Greek, again making no distinction between dead and living languages since his focus, too, was primarily on the development of foreign language literacy. 
For developing skill in speaking, Marcel stresses that, in addition to the grammar teaching procedures described above, words and phrases should be repeated after the teacher, in chorus ( 1820 : 55), with particular attention being paid to accurate imitation, since 'it is not by reading alone that we can acquire the pronunciation of a foreign language' (I820: 40). Later, Marcel was to be particularly scathing with regard to Hamilton's fifth principle that 'the simple sounds of all languages being, with few exceptions, identically the same, it must be as easy for an Englishman to pronounce French as English, when taught, and vice versa' (Hamilton, I829: I0). By contrast, Marcel emphasizes that 'there exist in all languages, sounds peculiar to each' (I820: 45); hence the difficulty of acquiring accurate pronunciation, and the need for a correct model to be provided (I820: 38 ). In a later critique he regretted the unfortunate result of Hamilton's cavalier attitude to pronunciation 'that hundreds of Hamiltonian teachers teach French, though they cannot speak it' (I833: vii). In order to develop the speaking skill, a certain proportion of each lesson should be devoted not only to pronunciation but also to oral sentence formation exercises, using words just learned (I820: 57).

While he continued to work as Chancellor in the French Consulate in Patrick Street (Pigot, I824: 264), Marcel's own French classes were gaining increasing favour in the local Cork community. One of his pupils was the young painter Daniel Maclise (I806-I870), a Cork native whose portrait of Marcel was exhibited locally in I828 (according to The Cork Constitution of 27 May I828) and who subsequently went on to become well known in England as a portraitist, caricaturist and historical painter (Arts Council of Great Britain, I972; Turpin, 2004). Numerous members of the local establishment also learned French with Marcel, including the Catholic and Protestant Bishops of Cork, the Governor-General of the province, and members of the clergy, the magistrature and the medical fraternity. In I830, following the July revolution, the French consulate in Cork was closed and Marcel became a mere 'consular agent', necessitating — presumably — an even greater reliance on teaching as a source of income. It appears that in the early I830s he organized a series of French lessons in London and - inspired perhaps by the contemporary renown of Hamilton and Jacotot - attempted to gain wider support for his own 'Méthode Marcellienne', privately printing a textbook with an extensive methodological introduction under a semi-pseudonym, 'Annibal Marcel' (I833). Marcel's use of a pseudonym for this neglected publication may be explained by his continuing hopes for advancement within the French diplomatic service, and the perceived incompatibility of this goal with language teaching activities. Indeed, a request he made in I843 to become full consul in Cork appears to have been turned down partly because of these outside interests.

In the long preface to his 1833 textbook, Marcel differentiates his suggestions from those of Hamilton, Jacotot and another rival, Dufief, stating that their methods 'require a great deal of study at home, depend upon memory, and leave the pronunciation to chance, as the written language is learnt before the spoken' (I833: xxv). The alternative he presents in 1833 is a system specifically designed for the classroom, involving 'the known assisting in the acquirement of the unknown'. First an English 
sentence is read aloud (this represents 'the known') and then a variety of activities relating to the French equivalent are engaged in: 'hearing and repeating'; 'hearing, repeating, and interpreting', where the teacher breaks down the French sentence, translating its individual (phrasal) constituents back into English; 'first step decomposition' (of the model sentence), where students attempt to translate into English new sentences which contain different combinations of phrasal constituents already memorized; and 'second stage decomposition', where students attempt to translate new English sentences into French. These are followed by reading aloud and writing activities involving the newly learned material. Two innovative features of this procedure might be remarked upon: Marcel's insistence (in contrast with Hamilton) on the translation and memorizing of phrases as opposed to words (I833: xvii), and the oral nature of the (translation) exercises proposed (I833: xx). As in his I820 essay, Marcel appears concerned to develop proposals specifically for the classroom teaching of living languages: as he says, 'a method, to become a national one, must be calculated for the masses, and not for adults only, or for such as know the grammar of their own language [...] I have had in view, the grand question of teaching living languages' (I833: xxii).

If Marcel was hoping for success on a grand scale in promoting his method in London, it is clear that this ambition was not realized; instead, he returned to Cork and again took up his consular duties and language teaching activities there. In I840 his services for France were rewarded with the post of 'honorary consul', which attracted a salary of Iooo francs and made him, presumably, less dependent on income from his teaching. However, his ambitions to become titular consul were thwarted due to official disapproval of his business activities and of his independence with regard to the consul general in Dublin. Directories published between 1842 and 1856 (consulted in the Local Studies Department, Cork City Libraries) provide evidence that Marcel was working as French consul and teacher of French at 47 or 48 Grand Parade, one of the main streets in the centre of the city.

The year I 848 saw the fall of Louis-Philippe in France and the proclamation of the Republic, followed by the ascendancy of Louis-Napoleon. Under the new regime, Marcel's diplomatic aspirations were better satisfied, not with the promotion he had coveted, but with his admittance to the Légion d'Honneur in I850, and a doubling of his salary in I853. By this time, Marcel was approaching retirement, and he had not apparently published anything on language teaching since his I 820 and I 833 contributions, which had hardly been noticed either in England or elsewhere. The year I853, however, saw the publication - again, for an English-speaking readership - of his monumental work in two volumes, Language as a Means of Mental Culture and International Communication. (Subsequently, in I855, Marcel produced an abridged, adapted French version.)

In this work, Marcel takes up and expands upon a number of ideas first expressed in his I820 essay, but in a much more systematic manner and with some shifts of emphasis. Thus, he continues to argue for the importance of studying living as opposed to classical languages, but he now highlights as a reason for this the development of 'mental culture' in addition to the more utilitarian reasons ('international 
communication') first provided in his I820 essay. In his I853 work Marcel expands in particular, though, on the idea that language learning should be viewed in terms of the development of four skills (which he terms 'branches'), devoting attention to how these skills should be ordered in a curriculum and providing a wealth of practical ideas for the teaching of each skill. Marcel here emphasizes the distinction between 'impression' - involving the receptive skills of listening and reading — and 'expression' - involving the productive skills of speaking and writing - whereas in his previous (I820 and I833) works he had appeared more concerned to distinguish the teaching of the spoken language from that of the written. His criteria for ordering the skills in a curriculum are now: (I) the stage of maturational development of the learner, and (2) the educational value of resulting classroom activities (the latter concern reflecting his new emphasis on the educational as well as utilitarian value of foreign language study). These new emphases lead him to suggest that reading should come first in a curriculum for secondary school education, although younger learners should start with the spoken language. Thus, the ordering of skills work for secondary school teaching is: reading, followed by listening, speaking and writing, in that order. In Marcel (I820; I833) all of these skills had been included in every lesson, with no obvious priority being given to any of them.

The disadvantage of the emphasis on reading which Marcel now proposes for secondary school is that it is to be taught in isolation from the spoken language (contrast his earlier emphasis on the importance of pronunciation). This is consistent, logically, with his arguments for the educational value of language learning and the priority which needs to be accorded to 'impression' in a method based on 'natural' learning processes, but it seems hard to carry out in practice. The principal merit of Marcel (I853) - its balanced, rational mode of argumentation in favour of differentiating approaches according to objectives, age of the learner and type of target language (classical or modern) - therefore contributes also to its main weakness: a certain over-rigidity with regard to separation of the language skills.

During his retirement, Marcel issued a number of publications on language teaching, which tended, largely, to restate or exemplify ideas already expressed in his I853 masterpiece. Marcel (I867) (which, this time, appeared first in French and was then issued in an American version in I869) is largely a summary of certain parts of Marcel (I853), while Marcel (n.d.) (dated I875 by Anon. I982) is a small pamphlet in French in which he attempts to provide a simplified version of his ideas for a wider audience. The back cover of this pamphlet provides a succinct summary of the major principles underlying what Marcel was by now calling his 'Méthode rationelle', as it had developed out of his I853 work. In the I870s, Marcel also brought out a number of learning materials, including synoptic tables for the learning of English grammar (1872) and reading materials (I873). When he died (on I7 January I876), he appears to have been working on a Grammaire pratique et comparée of the French and English languages (Marcel, n.d.: front inside cover), an apparently unfinished project which recalls the opening pages of his I820 essay, where he criticized the pedagogical grammars available at the time. 


\section{A neglected applied linguist?}

Although, as we have seen, Marcel's writing career spanned more than fifty years, the development of his ideas over time has not previously been explored. The few writers to highlight his achievements (Titone, I968; Darian, I972; Tickoo, I982; I984; Howatt, I984/2004; I993; and Roberts, I999) have tended to focus on particular works, not the full oeuvre, which has itself only recently been established (in Howatt and Smith, 2000); nor, with the exception of Howatt (I984/2004), have they attempted to investigate Marcel's biography and situate his ideas in the context of his overall career. A general failure to establish basic facts of bibliography and biography has, indeed, resulted in some notable errors of interpretation, among them Tickoo's (I982; I984) attribution of Marcel (I820) and Marcel (I853) to different authors, and Titone's (I968: 33) claim that Marcel emigrated to the USA (presumably because the book considered by Titone was published there in I869).

Additionally, although the originality and magnitude of achievement of Marcel's I853 work, in particular, has been emphasized by a few historians of language teaching (in particular Howatt, I984/2004; see also Tickoo, I984; Roberts, I999), it is important to acknowledge that his ideas were neglected by his contemporaries, had little apparent influence subsequently, and have received very few appreciations overall (in his native France, for example, Marcel's work appears to have remained completely unknown). Thus, before we turn to the issue of whether Marcel was in fact an applied linguist (avant la lettre), it will be useful, on the basis of the above overview of his career and developing ideas, to consider some possible reasons why his work has been so neglected:

I. Marcel was, at times, prevented by diplomatic ambition from associating his name with the 'outside interest' of language teaching (presumably this is why he wrote under a pseudonym in I833).

2. Until relatively late in his career he wrote primarily in English rather than French (possibly due to the same compunctions as in I above), thus gaining little renown in France.

3. Marcel was too far 'ahead of his time', at least in an Irish/British context, to gain much of a readership for serious arguments in favour of modern (as opposed to classical) languages, let alone for ideas on methodology; there was not yet a sufficiently large body of interested teachers or academics to read his works.

4. Marcel's earliest ideas on methodology, with their focus on oral work in the target language, were particularly ahead of their time. Later in the century Marcel moved to a position of advocating 'reading first' for secondary pupils, but this ran counter to the prevailing trend among progressive teachers at that time towards a spoken language focus.

5. The pan-European Reform Movement of the last two decades of the century (see Howatt and Smith, 2002) represented the first opportunity for a work of the seriousness of Marcel (I853) to obtain the readership it deserved. However, not only had Marcel associated himself by this time with a 'reading first' approach, but also his ideas were justified according to educational considerations, not the linguistic (phonetic) arguments favoured by the Reformers. 
6. Ever since the Reform Movement, indeed, progressive language teaching theory has tended to be dominated by relatively utilitarian, linguistics-related, phonocentric conceptions (Pennycook, I994: I26-4I) with little reference to educational considerations such as those presented by Marcel in I853.

So was Marcel an applied linguist? The answer to this question depends largely on our conception of what applied linguistics is, or should be concerned with, and herein lies the value of this kind of exercise - to clarify, in the mirror of history, what we mean by applied linguistics today, and also what - from an alternative perspective - it could mean beyond preconceptions inherited from the past.

If we construe this field of activity as a matter of applying linguistic theory or existing linguistic descriptions to practices such as language teaching ('linguistics applied' in Widdowson's formulation: e.g. Widdowson, 2000), then no, Marcel was not an applied linguist. Henry Sweet (I8I5-I9I2) and other members of the 'Anglo-Scandinavian School' (Linn, 2008) were more plausible precursors of this kind of applied linguistics. Whereas for Sweet, along with others involved in the Reform Movement of the late nineteenth century (see Howatt and Smith, 2002), the new science of phonetics was 'the indispensable foundation' of the practical study of languages, the academic linguists (or rather philologists) of Marcel's day were not much concerned with the description of living languages; in other words, there were as yet no particularly relevant linguistic theories or descriptions available which could be usefully applied to the teaching of modern languages.

The same considerations apply even if we take applied linguistics to be more of a problem- than a theory-driven kind of enterprise, so long as potential solutions are still conceived as necessarily linguistic in nature. Early in the twentieth century Harold E. Palmer (I877-I949) took up this kind of problem-driven but linguistically oriented position (see Smith, I999), and was therefore a more fitting predecessor than Marcel to those such as Widdowson who have argued for and exemplified a similar position in their work.

There is, however, a current conception of applied linguistics which Marcel can be seen to predate, and that is the one argued for most cogently by Brumfit (e.g. I997). As Brumfit emphasized, 'many researchers explore linguistic issues, but I did not experience language teaching as defined primarily by linguistic factors, so the other factors need investigation, if only to offset the dominance of linguistically oriented work' (I997: 89). Brumfit's own problem-focused 'working definition of applied linguistics' as 'the theoretical and empirical investigation of real-world problems in which language is a central issue' (I997: 9I) seems to take in Marcel's work quite well. ${ }^{3}$

Despite his apparent lack of impact, Marcel was certainly a major theorist of language teaching, and one who drew sustenance primarily from contemporary educational not linguistic theory, in combination with insights from his own teaching experience. Indeed, whereas insights from experience predominate over theory in his

3 While it cannot be said that there is either a fixed or a dominant conception of applied linguistics today, Brumfit's definition has gained considerable currency. This is evidenced by a recent special issue of the leading journal in the field, Applied Linguistics (Cook and Kasper, 2005), which took his definition as its starting point and 'Applied Linguistics and Real-World Problems' as its theme. (See also Widdowson, 2006: I6I.) 
early (I820; I833) works, in the much more substantial and considered (I853) work Language as a Means of Mental Culture and International Communication the tables are turned: to adopt/adapt Widdowson's distinction between linguistics applied and applied linguistics, this book exemplifies what might be termed an 'educational science applied' approach to language teaching (indeed, this is made quite clear in the subtitle of the I855 French version: Basic Principles of Education, with Special Application to the Study of Languages (my translation)). Thus, the first volume of Marcel (I853) begins with three chapters treating general educational issues before attention is turned to foreign languages. Principles for modern language teaching are then discussed in relation to the teaching of the native tongue within school education, before attention is focused more specifically on foreign languages in the second volume. This contrasts with Henry Sweet's linguistics applied approach in his The Practical Study of Languages (I899), where six chapters on general linguistic (particularly phonetic) issues precede the rest of the book's discussion of principles and methods for learning or teaching languages.

Like Sweet, Palmer and the post-World War II applied linguists after him, Marcel was concerned to offer a principled approach to the development and selection of methods, in opposition to unthinking acceptance of hidebound tradition and of patented but 'wrong-headed' progressive methods alike:

It is time to reject the worn-out machinery of our forefathers. Let us apply to mind, as we have done to matter, new powers and new processes. Let a rational system of learning languages bring men of all nations into communion, as steam has brought them into contact. (Marcel, I867: 228)

Clearly, then, Marcel was a neglected pioneer in the overall nineteenth-century movement to place the study of living languages on the same footing in the school curriculum as classical languages. Later in the century, justifications for a specific modern language pedagogy were found in the new science of phonetics. Writing, however, before the time when linguists (philologists) were much concerned with living languages, Marcel reminds us, above all, that educational considerations should be seen as an important source for language teaching theory:

as man is endowed with a diversity of innate powers, given him for a wise purpose, and differing in energy in each individual, it is the duty of the educator to study the human constitution and to cultivate all these powers in the child entrusted to his care. (I 853 / II: 3I9)

Language teaching, from this perspective, takes its place alongside other subjects in the school curriculum as a means not only for enhancing 'international communication' for practical purposes but also as part of an educational process of developing 'mental culture'. Thus, considering Marcel today — not only his works but also his lack of a legacy — can highlight at once how educational considerations deserve to be given more of a place at the applied linguistics table (cf. Stern, 1983) and how dominant the linguistics orientation in mainstream language teaching theory has been for the last I20 or more years. 


\section{Conclusion}

Despite his achievements in print, Marcel never gained much fame in his own day, and failed to be acknowledged within the phonetics-oriented Reform Movement. In this article I have suggested that it is precisely this phenomenon of the neglect of Claude Marcel by his contemporaries as well as by subsequent generations which should make him of interest to applied linguists today. As I hope has become clear, the fact that we have known so little about Claude Marcel or his work itself says much about the way applied linguistics has privileged and still continues to privilege certain types of knowledge over others. By the same token, historical investigation can be seen as an important step towards revealing the limitations of current, historically constituted paradigms and might even serve to support alternative conceptions of the nature of applied linguistics itself.

Thus, on the basis of original historical research into his life and analysis of his writings, I have argued in this article that Marcel's relevance today lies in the substantial example he provides of an 'applied linguistic' approach based on educational insights and not primarily on linguistic considerations.

\section{References}

Anon. 1982. Personal written communication from Ministère des Affaires Étrangères de la République Française (archives et documentation) outlining the consular career of Claude Marcel, obtained by A. P. R. Howatt during the preparation of Howatt (1984) and referred to here with his permission.

Arts Council of Great Britain. 1972. Daniel Maclise (I806-I870): [Catalogue of an exhibition at] National Portrait Gallery, London, 3 March-I6 April 1972, National Gallery of Ireland, Dublin, 5 May-I8 June I972 (London: Arts Council of Great Britain).

Brumfit, Christopher. 1997. 'How Applied Linguistics Is the Same as Any Other Science.' International Journal of Applied Linguistics, 7(I): 86-9I.

Coleman, James. I909. 'Two Franco-Cork Professors.' Journal of the Cork Historical and Archeological Society, I5 (2nd series): 99-I00.

Cook, G. \& G. Kasper eds. 2005. Applied Linguistics (special issue on 'Applied Linguistics and Real-World Problems') 26(4).

Crawford Municipal Art Gallery. n.d. Cork Art History 1826-1850. Part of Cork Art History I800-I900: A Chronological History of Art and Architecture in Nineteenth Century Cork Incorporating a History of the Crawford Art Gallery and the Crawford School of Art. http://www.crawfordartgallery.com/I826-I850, accessed II August 2006.

Darian, S. G. 1972. English as a Foreign Language: History, Development, and Methods of Teaching (Norman: University of Oklahoma Press).

Hamilton, J. 1829. The History, Principles, Practice, and Results of the Hamiltonian System, for the Last Twelve Years; with Answers to the Edinburgh and Westminster Reviews; and His Public Lecture in Liverpool, on the I8th of March, I829; with Instructions for the Use of the Books Published on this System (Manchester: T. Sowler, Courier and Herald Office).

Howatt, A. P. R. 1984/2004. A History of English Language Teaching. Second (2004) edition co-authored with H. G. Widdowson (Oxford: Oxford University Press).

- I993. 'Claude Marcel (I793-I876) and the Role of Reading in a Model of Language Pedagogy in the Mid Nineteenth Century', in Further Studies in the History of Reading, ed. by G. Brooks, A. K. Pugh \& N. Hall (Widnes: United Kingdom Reading Association), 6I-66.

— \& R. C. Smith eds. 2000. Foundations of Foreign Language Teaching: Nineteenth-Century Innovators, six volumes (London: Routledge). Works by Marcel are in Volumes 2 and 3.

— \& R. C. Smith eds. 2002. Modern Language Teaching: The Reform Movement, five volumes (London: Routledge). 
Jacotot, J. I824. Enseignement universel: langue étrangère (Leuven: de Pauw).

Linn, A. 2008. 'The Birth of Applied Linguistics: The Anglo-Scandinavian School as "Discourse Community".' Historiographia Linguistica, 35(3): $342-384$.

Marcel, C. V. A. I820. Practical Method of Teaching the Living Languages, Applied to the French, in which Several Defects of the Old Method are Pointed Out and Remedied (London: Hurst, Robinson).

- [under pseudonym 'M. Annibal Marcel'] I833. Méthode Marcellienne, ou méthode naturelle théorisée [Preface in English] (London: Author).

- I853. Language as a Means of Mental Culture and International Communication; or, Manual of the Teacher and the Learner of Languages (London: Chapman and Hall). Two volumes.

- I855. De l'étude des langues. Première partie. Premiers principes d'éducation avec leur application spéciale à l'étude des langues (Paris: Borrani et Droz). Adapted translation of Marcel (I853).

—. I867. L'Étude des langues, ramenée à ses véritables principes, ou L'art de penser dans une langue étrangère (Paris: Borrani).

- I869. The Study of Languages Brought Back to Its True Principles, or the Art of Thinking in a Foreign Language (New York: Appleton). Adapted translation of Marcel I867.

- I 1872. Tableau synoptique pour servir à l'étude pratique de la langue anglaise (Paris: Boyer). As referenced in Marcel (n.d.).

- I873. Histoire anecdotique de l'Angleterre; Anecdotal History of England (Paris: Boyer). As referenced in Marcel (n.d.).

- n.d. [I875?]. Méthode rationelle, suivant pas à pas la marche de la nature pour apprendre les langues étrangères avec ou sans maître: exposé de la méthode (Paris: Boyer).

Pennycook, A. 1994. The Cultural Politics of English as an International Language (Harlow: Longman).

Pigot, J. \& others I824. Pigot and Co.'s City of Dublin and Hibernian Provincial Directory Containing a Classification of the Nobility, Gentry, Clergy, Professional Gentlemen, Merchants, and Manufacturers of Dublin and upwards of Two Hundred \& Twenty of the Principal Cities, Seaports and Towns of Ireland, Alphabetically Arranged in Provinces (London: Pigot).

Roberts, J. T. 1999. Two French Language Teaching Reformers Reassessed: Claude Marcel and François Gouin (Lewiston, NY: Mellen).

Smith, R. C. I999. The Writings of Harold E. Palmer: An Overview (Tokyo: Hon-no-Tomosha). http:// www.warwick.ac.uk/ elsdr/WritingsofH.E.Palmer.pdf, accessed I3 July 2009.

Stern, H. H. I983. Fundamental Conceptions of Language Teaching (Oxford: Oxford University Press).

Sweet, H. I899. The Practical Study of Languages: A Guide for Teachers and Learners (London: Dent).

Tickoo, M. L. I982. 'James Hamilton and C. V. A. Marcel: a review of language teaching in the I82os.' World Language English, I(3): I74-178.

- I984. 'Claude Marcel and "une méthode rationelle".' World Language English, 3(4): 240-244.

Titone, R. I968. Teaching Foreign Languages: An Historical Sketch (Washington, DC: Georgetown University Press).

Turpin, J. 2004. Maclise, Daniel (bap. I806, d. I870). Oxford Dictionary of National Biography (Oxford: Oxford University Press). http://www.oxforddnb.com/view/article/I7682, accessed I3 July 2009.

Widdowson, H. G. 2000. 'On the Limitations of Linguistics Applied.' Applied Linguistics, 2I(I): 3-25.

—. 2006. 'Christopher Brumfit (I940-2006).' Applied Linguistics, 27(2): I6I-I63.

\section{Notes on contributor}

Dr Richard Smith is an Associate Professor in the Centre for Applied Linguistics, University of Warwick, UK. He has been involved in teacher education and research in the field of teaching English as a foreign language for the last twenty years. In 2002 he established the Warwick ELT Archive (http://www.warwick.ac.uk/go/elt_archive), a unique collection of historical materials relating to the development of ELT (English Language Teaching for speakers of other languages) over the last I 30 years.

Correspondence to: Dr Richard Smith, Centre for Applied Linguistics, University of Warwick, Coventry CV4 7AL, UK. e-mail: R.C.Smith@warwick.ac.uk 